Original Research Paper

\title{
The Study on the Roles of Predators on Asian Corn Stem Borer, Ostrinia furnacalis Guenee (Lepidoptera: Pyralidae)
}

\author{
La Daha, Nur Amin and Tamrin Abdullah \\ Department of Plant Protection, Faculty of Agriculture, Hasanuddin University, Makassar 90245, South Sulawesi, Indonesia
}

\author{
Article history \\ Received: 11-10-2015 \\ Revised: 26-12-2015 \\ Accepted: $31-12-2015$ \\ Corresponding Author: \\ La Daha \\ Department of Plant Protection, \\ Faculty of Agriculture, \\ Hasanuddin University, \\ Makassar 90245, South \\ Sulawesi, Indonesia \\ Email: drladaha@yahoo.com
}

\begin{abstract}
The study aimed to investigate the role of predators in preying the larvae and pupae of corn stem borer, Ostrinia furnacalis Guenee (Lepidoptera: Pyralidae) was conducted in the farmer corn field during 2011. Two plant hills each of which 6 meter away were prepared one of which unglued and the other one glued for ground and canopy predators. On each plant, 5 larvae instar- 2 and or -3 were made available (2 larvae at internode near the ground surface, 1 near the corn ear, at internode between ear and tassel and at the upper top internode respectively). The experiment was carried out with 10 replications so there were 20 plant hills prepared. The experiment was also carried out with the same procedures for pupae. The predators, visit frequency and the number of preys consumed by predators were recorded. The results indicated that there were 5 groups of predators i.e., ants, spiders, cricket, Coccinella sp., Chrysopa sp. and Paederus sp. were found to visit larvae and pupae on plant corn. The ant predator visit more frequently the prey larvae and pupae on both unglued and glued plants and only this predator recorded to prey larvae with the mean of $2.5(50 \%)$ and $1.9(38 \%)$ and pupae with the mean of $3.2(64 \%)$ and $3.0(60 \%)$ in $14 \mathrm{~h}$ period on glued and un-glued plants respectively. The ant, Solenopsis sp. found in this study can really be promoted as biological control for Asian corn borer.
\end{abstract}

Keywords: Corn, Predator, Biological Control, Ostrinia furnacalis

\section{Introduction}

The Asian corn borer, Ostrinia furnacalis Guenee (Lepidoptera: Pyralidae) is the most important pest attacking corn plant in Southeast Asian Countries (Javier et al., 2005; Afidchao et al., 2013) and in China (Liu et al., 1998). The Asian corn borer was reported to produce in yield loss up to $20-80 \%$ in Philippines (Nafus and Schereiner, 1991), 50-96\% in Thailand (Areekuls et al., 1966) and up to $80 \%$ in Indonesia (Nafus and Schereiner, 1987).

In Indonesia corn is the second important plant after rice producing food. In order to fulfill the national need (1.5 million tons a year) of food, the government tend to help the farmers to increase corn productivity, but the most important limiting factor reducing corn production target is due to insect pest damage, Asian corn stem borer. Up to the present time no available control technique might completely solve the problem of corn stem borer damage so the farmers are generally dependent on the use of conventional insecticide application even though this control practice might produce various environmental negative effects. In some countries as China, the augmentative release of egg parasitoid, Trichogramma sp. was widely used (Nafus and Schreiner 1991; Liu et al., 1998) and in Indonesia the augmentation produced a parasitization up to $71-90 \%$ (Nonci, 2005). To produce a large number of individuals for augmentation, the parasitoid must be mass reared and this might not be practicable in the farmer level.

In recent trend issues, the presence of endophytic fungi on various plant that protected the associated plant from the attack of insect pests and plant pathogen was reported by many authors as for example Amin et al. (2014) isolated endophytic fungi i.e., Beauveria sp, Trichoderma sp., Aspergilus sp. and Fusarium sp. from health or undamaged cocoa plant. Application of Beauveria with $10^{6} \times \mathrm{mL}^{-1}$ conidia suspension on cocoa pod borer eggs produced more than $90 \%$ egg 
mortality. Beauveria also had been recorded to produce a great impact on the egg mortality of ear worm on corn plant in the field and this also needed to be investigated for Asian corn borer.

It is realized that an alternative control technique which could be implemented by the farmers is still needed. In the field there might be a number of predators naturally present in the corn plant ecosystem but their roles especially associated with a destructive corn stem borer not exactly understood. The predators are generally polyphagous which might attack all or most available preys in agroecosystem in their range. The study was carried out to record the natural predators and their role on predation of Asian corn borer. If a predator produce a significant role in preying and reducing the number of an existing pest, an effort is needed to maintain the predator existence before or during corn plant growth.

\section{Materials and Methods}

The trial was carried out on a corn farmer field in Takalar District, South Sulawesi, Indonesia. The trial was designed in such a way to observe the predators which occupied underground and canopy plants and their role on the Asian corn stem borer.

The insect developmental stages used in the trial were larvae instar- 2 or instar- 3 and pupae that were collected from corn farmer field. Larvae instar-2 and instar-3 and pupae were directly used for experimental material and larvae instar-4 and instar-5 were further reared to obtain pupae. In the first step of the study was made in $24 \mathrm{~h}$ to observe daily activity of natural predators and the information obtained then used for intensive observation of the prey consumption by predators.

Two hills of two stem borer attacked plants each of which six meters away were selected for ground dwelling and canopy predators study. Since the trial was done in 10 replications, 20 hills of corn plants then selected consequently. There were five larvae made available in each plant hill so if the hill with less than five larvae naturally infested plant was added with larvae that had been collected as mentioned above and if the hill with more than five naturally infested plant, larvae were taken out or removed. Since the stem borer larvae generally attack the plant at all position of the corn stem from underground part, middle and at internode near the tassel, the larval experimental materials were then arranged in such a way that two at the lower internode near ground surface, one at each near the corn ear, at internode between ear and tassel and at the upper internode respectively. The plants trial for ground dwelling predators was covered with a cage of $170 \times 60 \times 60 \mathrm{~cm}^{3}$ to prevent the entrance of canopy predators and the cage near the ground surface left opened $( \pm 10 \mathrm{~cm})$ to facilitate the entrance of predators to climb up. The plants trial for canopy predators on the other hand was left opened but the first internode near ground surface was glued and all the corn leaves touching the ground surface were cut away to prevent ground predators invade the plant trial. The same procedure was made for pupal prey.

Since from preliminary observation that predators generally active at $16.00-24.00 \mathrm{PM}$, the observation to record visit frequency was concentrated on this period of time, but the number of preys consumed by predators were made in next 06.00 AM.

\section{Results}

The results indicated that the predators generally more actively visit the plants trial between 16.00 and 24.00 PM. During this period of time, the predators visiting the larval and/ or pupal preys on the corn plants belong to insect and arachnid predators. The insect group predators consisted of ants which belong to Solenopsis sp. (Hymenoptera: Formicidae), cricket (Orthoptera: Gryllidae), Coccinella sp. (Coleoptera: Coccinellidae), Chrysopa sp. (Neuroptera: Chrysopidae) and Paederus sp. (Coleoptera: Staphylinidae) while the arachnid predator is only spider was recorded. Ants, cricket, paederus and spider are belong to ground-dwelling predators while Chrysopa and Coccinella are predators that inhabit plant canopy.

Ant predator was recorded to visit both larval and pupal prey more frequently and only this predator found consuming the available preys. Such other predators as cricket, Coccinella, Chrysopa, Paederus and spider on the other hand only visit both larval and pupal prey on both glued and unglued plant trials with a lower frequency of less than one (Table 1 and 2) in the period of $8 \mathrm{~h}$ (from 16.00 to $24.00 \mathrm{PM}$ ). In this period of time ant predators visit the larval prey on both unglued plants (ground dwelling predators plant trial) and glued plants (canopy predators plant trial) with the mean frequency of 1.8 and 1.5 respectively, the means of which are not significantly different by $F$-test $(p=0.05)$ (Table 1$)$. In the same period of time the ants visit pupal prey on unglued and glued plants with the mean frequency of 1.4 and 1.9 respectively and also not sig-nificantly different between the means (Table 2).

A number of workers from the nest underground searching or seeking food and climbing up the corn plant. As a worker find a larval prey or a hole made by a larva, the ant then recruit the other workers and move together toward the target and they then remove the frush around the hole. A worker then enter the hole and followed by a number of other 5-8 workers and they then handling the prey victim. The larva initially show a defense reaction by moving it body. But since the 
number of recruited workers increasing with the time, after $1 \mathrm{~m}$ then the ants successfully subjugated or knockdown the larval prey and they then bring it out from the hole (Fig. 1). The ants then carrying the larval victim to the nest (Fig. 2).

In the period of $14 \mathrm{~h}(16.00 \mathrm{PM}-06.00 \mathrm{AM})$ the mean number of preys consumed by ants on unglued and glued plants were 1.9 and 2.5 larvae/plant hill (Table 3) or ants consumed 38 and $50 \%$ from five larvae made available on each plant hill and not significantly different between the two means by $F$-test $(p=0.05)$. In the same period of time ants consumed more pupae compared to larvae with the mean of 3.0 and 3.2 pupae/plant hill (Table 4) or $60 \%$ and $64 \%$ from five pupae made available on unglued and glued plant and also these means not significantly different $(p=0.05)$.

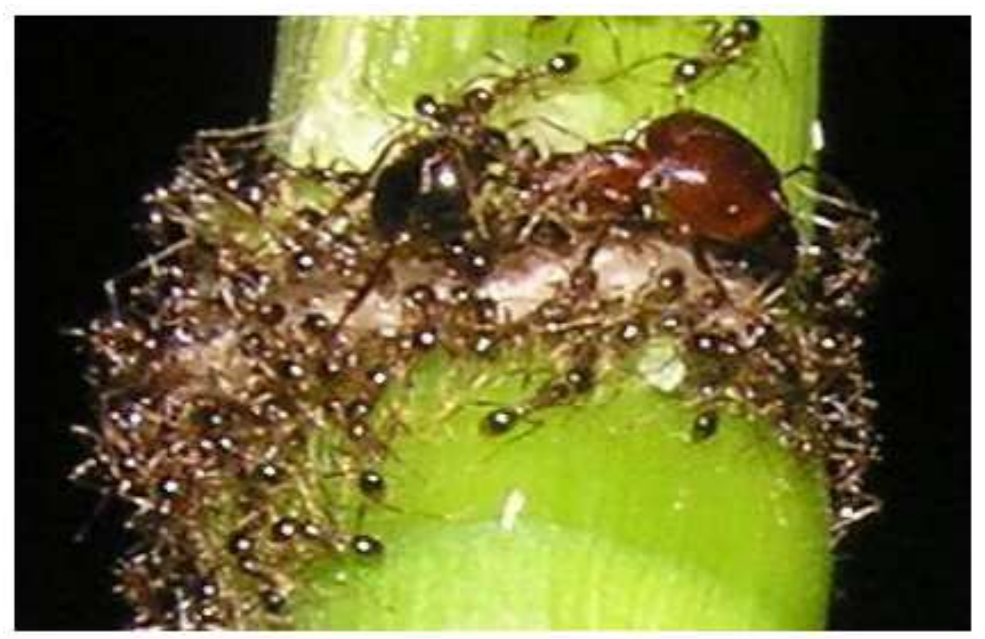

Fig. 1. The ant workers attacking the larval prey

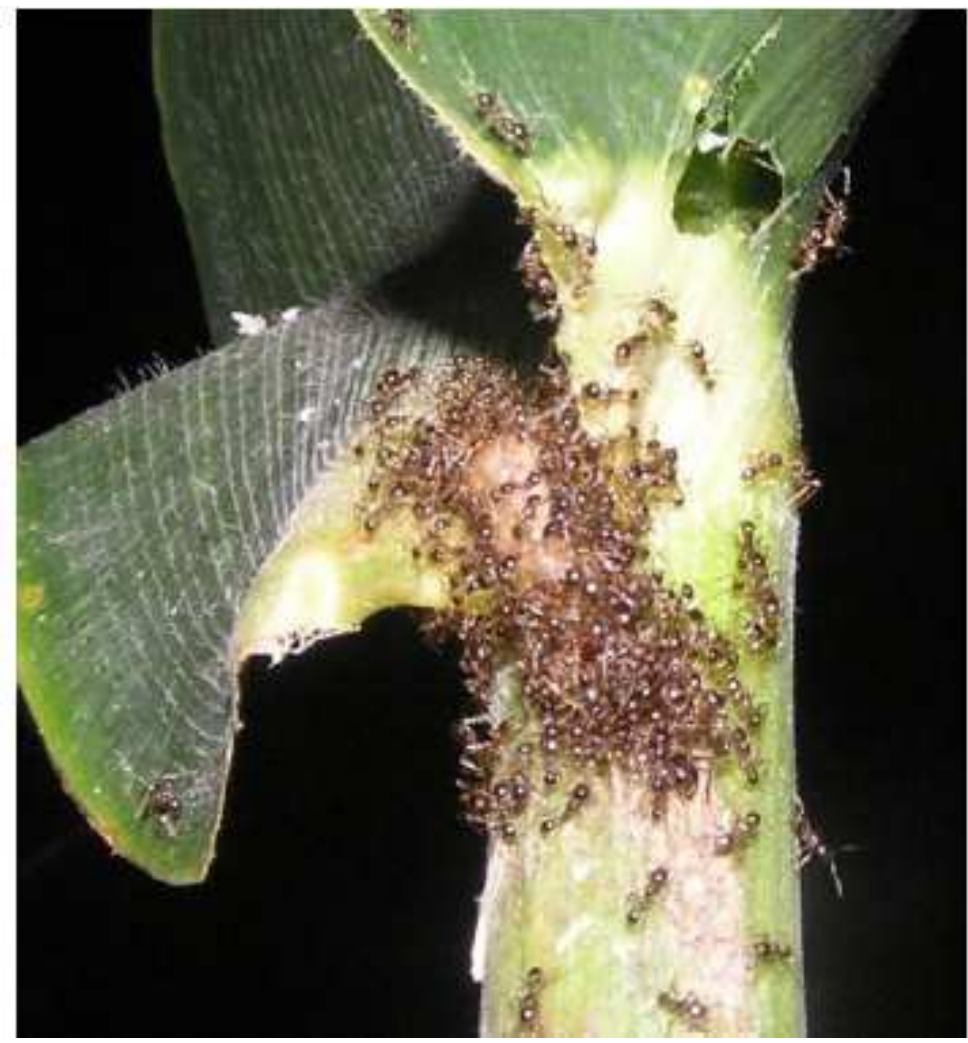

Fig. 2. The ant workers carrying the larval prey 
Table 1. Means of visit frequency to larval prey by predators on ground and crown plant trial during $8 \mathrm{~h}$ period (16.00 PM24.00 PM)

\begin{tabular}{lll}
\hline & Unglued plants (Ground & Glued plants (Crown \\
Predators & Preda-tor Plants Tri-al) & $1.5^{*}$ \\
\hline Ants & $1.8^{*}$ & 0.4 \\
Spider & 1.3 & 0.4 \\
Cricket & 0.0 & 0.0 \\
Coccinella sp. & 0.3 & 0.1 \\
Chrysopa sp. & 0.2 & 0.0 \\
Paederus sp. & 0.3 & Priants \\
\hline
\end{tabular}

*The means based on 10 replications not significantly different by analysis of variance, $F$-test $(p=0.05)$ : Calculated $F=0.5031$ and $\mathrm{F}_{(18 ; 0.05)}=4.41$

Table 2. Predator visit frequency to pupal prey on ground and crown plant trial during $8 \mathrm{~h}$ period (16.00 PM-24.00 PM)

\begin{tabular}{lll}
\hline & Unglued plants (Ground & Glued plants (Crown \\
Predators & Predator Plants Trial) & $1.9^{*}$ \\
\hline Ants & $1.4^{*}$ & 0.7 \\
Spider & 0.1 & 0.1 \\
Cricket & 0.0 & 0.0 \\
Coccinella $s p$. & 0.5 & 0.0 \\
Chrysopa sp. & 0.4 & 0.1 \\
Paederussp. & 0.3 & Trial) \\
\hline
\end{tabular}

*The means based on 10 replications not significantly different by analysis of variance, $F$-test $(p=0.05)$ : Calculated $F=3.0821$ and $\mathrm{F}_{(18 ; 0.05)}=4.41$

Table 3. Mean number larvae/plant hill consumed by ant predator during $14 \mathrm{~h}$ period (16.00 PM-06.00 AM)

\begin{tabular}{lll}
\hline Treatment & Larval position & Mean \\
\hline Unglued plants trial & Lower ground internode & 1.0 \\
& Near the ear & 0.3 \\
& Internode between ear and tassel & 0.3 \\
Glued plant trials & Last top internode & 0.3 \\
& Sub-total & $1.9^{*}(38 \%)$ \\
& Lower ground internode & 1.0 \\
& Near the ear & 0.4 \\
& Internode between ear and tassel & 0.7 \\
& Last top internode & 0.4 \\
& Sub-total & $2.5^{*}\left(50^{\circ}\right)$
\end{tabular}

*The sub total means based on 10 replications (plant hills) not significantly different by analysis of variance, $F$-test $(p=0.05)$ : Calculated $F=0.4538$ and $\mathrm{F}_{(18 ; 0.05)}=4.41$

Table 4. Mean number pupae/plant hill consumed by ant predator during $14 \mathrm{~h}$ period (16.00 PM-06.00 AM)

\begin{tabular}{lll}
\hline Treatment & Pupal position & Mean \\
\hline Unglued plants trial & Lower ground internode & 2.0 \\
& Near the ear & 0.6 \\
& Internode be-tween ear and tassel & 0.3 \\
& Last top internode & 0.1 \\
Glued plants trial & Sub-total & $3.0 *(60 \%)$ \\
& Lower ground internode & 2.0 \\
& Near the ear & 0.7 \\
& Internode between ear and tassel & 0.4 \\
& Last top internode & 0.1 \\
& Sub-total & $3.2 *(64 \%)$
\end{tabular}

*The sub total means based on 10 replications (plant hills) not significantly different by analysis of variance, $F$-test $(p=0.05)$ : Calculated $F=0.1304$ and $\mathrm{F}_{(18 ; 0.05)}=4.41$

\section{Discussion}

Indeed the ant predator that belong to Solenopsis sp. found in the study played a great important role in preying the Asian corn stem borer larvae and pupae. The ant predator performed an incredible capability that the other predators might not be able to do. The ants could be able to cross the part of the stem glued by 
constructing a bridge made from soil materials. This bridge also facilitate the such other soil-dwelling arthropod predators as cricket, Paederus sp. and spider (Lycossasp) to climb the plants and visit the prey on glued plant (Table 1 and 2) even though these predators did not consume the available preys.

In general ant including Solenopsis sp. is generalist or polyphagous predator that might attack every available prey both pests and beneficial organisms including insect species, other arthropods and nonarthropod. In the case of the corn stem borer studied although not observed it is believed that Solenopsis sp. recorded might attack or consume all such developmental stages as eggs and all instar larvae.

Solenopsis spp. is a popular soil-dwelling ant that had been reported by some authors in their roles for a potential biological control of wide range of such herbivores of various agricultural plants as coffee berry borer (Armbrecht and Gallego, 2007), earworm (Allen and Campos, 2008), brown plant hoper, Nilaparvata lugens on upland rice field (Way et al., 2002), apple snail, Pomacea canaliculata on irrigated paddy fields (Yusa, 2001). S. invicta worker densities was reported to have a negative association with all herbivores on cotton (Eubanks, 2001; Wickings and John, 2011) and with most herbivores on soybean plants (Eubanks, 2001). The red imported fire ant, Solenopsis is an important predator of boll weevil (Diaz et al., 2004; Fillman and Sterling, 1983; Sterling et al., 1984; Agnew and Sterling, 1981), beet armyworm (Diaz et al., 2004) and coleopteran and homopteran insect pests attacking sweet potato (Rashid et al., 2013).

As a general predator, ants might have more advantages compared to such other general predators as coccinelid beetle, chrysopid and paederus. Ant predators might attack various size of preys from smaller up to lager size and actively moveable as in the case of Asian corn borer larvae studied, but coccinelid beetle, chrysopid and paederus might be restricted to only relative small and moderate size and non or less actively moveable preys.

Coccinellid lady beetle was reported to prey on aphids prey (Cabral et al., 2011; 2009; Nedved and Salvucci, 2008) and the voracity increase if the predators encounter less mobile preys, insecticidetreated aphids. Paederus fuscippes preyed on brown plant hopper and white backed plant hopper nymphs (Padmavathi et al., 2008) while Chrysoperla carnea adult, green lacewing eat pollen honeydew but the larvae known to prey small insects from such as red spider mites, thrips, whitefly, the eggs of leafhoppers, leaf miners, psyllid and predominantly aphids (Bellows and Fisher, 1999).

It is believed that the smaller size of the prey as eggs or small larvae the more individuals might be preyed by ants since the recruitment of workers might take place in short time and the more rapidly transported to the nest as reported by Yijuan et al. (2007) for S. invicta. The less or unmovable preys the more individuals might also be preyed as in the case of Asian corn borer pupae recorded in this study.

Another advantage of various species of ant predators is a social insect in which a nest consist of a larger numbers of individuals including queens, soldiers and workers all of which need food and therefore the use of ant for pest biological control will produce a greater result compared to such other nonsocial predator as coccinelid, Chrysopid and paederus. The ants will protect a plant from the attack of all or most herbivores. On corn plant for example, the ant (Solenopsis sp.) recorded in this study will attack every herbivore as Asian corn borer and earworm both of which are the most destructive pests of corn plant. Another example the cocoa plants occupied by arboreal ant communities as fewer ant, Oecophylla smaragdina, Crematogaster sp., Dolichoderus sp. and Anoplolepis sp. resulted in free or less damage by cocoa pod borer, Helopeltis and stem borer attack (La Daha, 2002).

The problem in the field, the population density of ants might fluctuate during the year according to availability of food. In order to maintain population density before the prey available naturally, artificial died should be supplied periodically as we experienced for $O$. smaragdina in cocoa plantation before fruiting period. The population of Solenopsis ants as found in this study could also be maintained in the same way before the farmers grow the corn plants.

\section{Conclusion}

The ant, Solenopsis sp. could be promoted as an important biological control for pests attacking corn plants especially Asian corn borer, Ostrinia furnacalis.

\section{Acknowledgement}

We would like to thank to Andi NirmalaDiansari for help in coordinating and arranging field experiment. Special thank also addressed to the farmer who allowed us to carry out the experiment in his corn garden.

\section{Author's Contributions}

La Daha: Preparing all sections or parts of Manuscript: Abstract, introduction, and so on.

Nur Amin: Preparing Manuscript such as siting references according Guide to author and data analysis.

Tamrin Abdullah: Preparing Manuscriptsuch as Materials and Methods, Tables and Figure. 


\section{Ethics}

We ensure that our manuscript was based on the data obtained from an original research and never sent to elsewhere part or whole for publication so we believe that there will be no conflict of interest might occur consequently.

\section{References}

Afidchao, M.M., C.J.M. Musters and G.R. de Snoo, 2013. Asian Corn Borer (ACB) and non-ACB pests in GM corn (Zea mays L.) in the Philippines. Pest Manage. Sci., 69: 792-801. DOI: $10.1002 / \mathrm{ps} .3471$

Agnew, C.W. and W.L. Sterling, 1981. Predation of boll weevil in partially-open cotton boll by the red imported fire ant. Southwest Entomol., 6: 215-219.

Allen, E.K. and M. Campos, 2008. Effect of red imported fire ant, Solenopsis invicta ${ }^{1}$, on abundance of corn earworm, Helicoverpa zea $a^{2}$, on maize in Texas. Southwest Entomol., 33: 1-13. DOI: $10.3958 / 0147-1724-33.1 .1$

Areekuls, S., B. Valleluk, A. Vatanatagun, U. Skulpanich and P. Prachaudman et al., 1966. Some studies of the insect pests of corn in Thailand. Pacific Sci. Congress, Tokyo, Japan. 11: 22-33.

Armbrecht, I. and M.C. Gallego, 2007. Testing ant predation on the coffee berry borer in shaded and sun coffee plantations in Colombia. Entomol. Exp. Applicata, 124: 261-267.

DOI: $10.1111 / \mathrm{j} .1570-7458.2007 .00574 . \mathrm{x}$

Bellows, T.S. and T.W. Fisher, 1999. Handbook of Biological Control: Principles and Applications of Biological Control. 1st Edn., Academic Press, San Diego, ISBN-10: 0080533019, pp: 1046.

Cabral, S., A.O. Soares and P. Garcia, 2009. Predation by Coccinella undecimpunctata L. (Coleoptera: Coccinellidae) on Myzuspersicae Sulzer (Homoptera: Aphididae): Effect of prey density. Bio. Control, 50: 25-29.

DOI: $10.1016 /$ j.biocontrol.2009.01.020

Cabral, S., A. O. Soares and P. Garcia, 2011. Voracity of Coccinella undecimpunctata: Effects of insecticides when foraging in a prey/plant system.

J. Pest Sci., 84: 373-379.

DOI: $10.1007 / \mathrm{s} 10340-011-0373-2$

Diaz, R., A. Knutson and J.S. Bernal, 2004. Effect of the red imported fire ant on cotton aphid population density and predation of bollworm and beet armyworm eggs. J. Econ. Entomol., 97: 222-229. DOI: $10.1093 /$ jee/97.2.222
Eubanks, M.D., 2001. Estimates of the direct and indirect effects of red imported fire ants on biological control in Field crops. Bio. Control, 21: 35-43. DOI: 10.1006/bcon.2001.0923

Fillman, D.A. and W.L. Sterling, 1983. Killing power of the red imported fire ant (Hymenoptera: Formicidae): A key predator of the boll weevil (Coleoptera: Curculionidae). Entomophaga, 28: 339 344. DOI: $10.1007 /$ BF02372186

Javier, P.A., P.G. Gonzales, A.M. Rosales, R.V. Labios and L.L.Tamisin Jr, 2005. On-farm verification of IPM technologies developed for Asian corn borer against the corn earworm, Hel-icoverpa armigera (Hubner) in San Jose, Occidental Mindoro. Phil. J. Sci., 134: 57-62.

La Daha, 2002. The roles of ants on the infestation by Cocoa Pod Borer, Conopomorpha cramerella (Lepidoptera: Gracillaridae) on smallholding cocoa plantation in Dolago, Parigi, Central Sulawesi. Agritrop, 21: 108-111.

Liu, S.S., G.M. Zhang and F. Zhang, 1998. Factors influencing parasitism of Trichogramma dendrolimi on eggs of the Asian corn borer, Ostrinia furnacalis. BioControl, 43: 273-287. DOI: $10.1023 / \mathrm{A}: 1009984125066$

Nafus, D.M. and I.H. Schereiner, 1991. Review of the biology and control of the Asian corn borer, Ostrinia furnacalis (Lep: Pyralidae). Tropical Pest Manage., 37: 41-56. DOI: 10.1080/09670879109371535

Nafus, D.M. and I. H. Schereiner, 1987. Location of Ostrinia furnacalis (Lepidoptera: Pyralidae) eggs and larvae on sweet corn in relation to plant growth stage. J. Econ. Entomol., 80: 411-416.

DOI: $10.1093 /$ jee/80.2.411

Nedved, O. and S. Salvucci, 2008. Ladybird Coccinella septempunctata (Coleoptera: Coccinellidae) prefers toxic prey in laboratory choice experiment. Eur. J. Entomol., 105: 431-436. DOI: $10.14411 /$ eje.2008.055

Nonci, N., 2005. The use of egg parasitoid, Trichogramma evanescens Westwood to control the corn stem borer, Ostrinia funacalis Guenee in South Sulawesi, Indonesia. Proceedings of the National Corn Workshop, (NCW’ 05), pp: 548-561.

Amin, N., L. Daha and N. Agus, 2014. The study on the role of entomopathogenic fungal endophytes in controling the cocoa pod borer (Conopomorpha cramerella (Snellen)) (Lepidoptera: Gracillariidae) on cocoa plant. J. Entomol., 11: 142-152.

DOI: $10.3923 /$ je.2014.142.152

Padmavathi, C., G. Katti, A.P. Padmakumari and I.C. Pasalu, 2008. Prevalence, prey preference and predatory potential of Paederus fuscipes curtis and Ophionea sp. in Rice. J. Bio. Control, 22: 191-193. 
Rashid, T., C. Jian, T.V. James and J.M. Paul, 2013. Arthropod prey of imported fire ants (Hymenoptera: Formicidae) in Mississippi sweet potato fields. Insect Sci., 20: 467-71.

DOI: $10.1111 / 1744-7917.12003$

Sterling, W. L., D. A. Dean, D. A. Fillman and D. Jones, 1984. Naturally-occurring biological control of the boll weevil (Coleoptera: Curculionidae). Entomophaga, 29: 1-9. DOI: 10.1007/BF02372203

Way, M.J., G. Javier and K.L. Heong, 2002. The role of ants, especially the fire ant, Solenopsis geminata (Hymenoptera: Formicidae), in the biological control of tropical upland rice pests. Bull. Entomol. Res., 92: 431-437. DOI: 10.1079/BER2002185
Wickings, K. G. and R. John, 2011. Impact of the red imported fire ant (Hymenoptera: Formicidae) on Epigeic arthropods of cotton agroecosystems. Ann. Entomol. Soc. Am., 104: 171-179. DOI: $10.1603 / A N 10034$

Yijuan, X., Y. Lu, L. Zeng and G. Liang, 2007. Foraging behavior and recruitment of red imported fire Solenopsis invicta Buren in typical habitats of South China. Acta Ecol. Sinica, 27: 855-860. DOI: $10.1016 / \mathrm{S} 1872-2032(07) 60022-5$

Yusa, Y., 2001. Predation on eggs of the apple snail Pomacea canaliculata (Gastropoda: Ampullariidae) by the fire ant Solenopsis geminata. J. Moll. Stud., 67: 275-279. DOI: 10.1093/mollus/67.3.275 